\title{
Primary Hyperfibrinolysis as a Presentation of Extended Prostate Carcinoma
}

\author{
PABLO RUIZ-SADA, AROSTEGUI-URIBE NAHIA, GARAY-HIDALGO IKER, URIARTE-ELGUEZABAL KATALIN
}

Internal Medicine Department, HCU. Basurto (Bilbao), Spain

\begin{abstract}
Primary hyperfibrinolysis States are rare entities associated with different clinical scenarios and can be sometimes their first presentation. PHS outcome relies on the underlying cause. We introduce the case of a man presenting with a complex clotting abnormality malignancy related. Not having an accurate diagnosis hindered us to give an easy solution and compromised the prognosis overall. Misdiagnosing a severe entity often leads to fatal outcomes. We want to highlight the rarity of our case, the challenging differential diagnosis and the importance of being aware of PHS. Because our patient appeared to have an extended carcinoma, definitive treatment was not an option on our case.When an uncommon and challenging disease is presented, having all the clues is mandatory to succeed.
\end{abstract}

Key words: Hyperfibrinolysis, prostate carcinoma, paraneoplastic syndrome, clotting cascade, haemorrhage.

\section{INTRODUCTION}

A primary hyperfibrinolysis state (PHS) is a non-compensatory fibrinolysis overexpression [1]. The name itself is a misnomer because it is due, in turn, secondary to genetic based diseases or to several disorders such as chronic liver failure or malignancies [2]. It is linked to hematologic malignancies, as well as solid tumors such as prostate and breast carcinoma. In these settings it is more common to find a Disseminated Intravascular Coagulopathy (DIC) with hyperfibrinolysis features than a PHS. Besides, there is a current opinion that when a hyperfibrinolytic state develops in the setting of a solid tumor it is always related to a DIC rather than a PHS [3]. Thus, it is the paraneoplastic expression of a widespread uncontrolled disease, in which treatment response relies on the evolution of the tumor. As the natural history of the underlying cause often leads to fatal outcomes, overall prognosis is poor.

\section{CASE REPORT}

We introduce the case of a 72-year-old male admitted to the ward with mild bleeding and coagulopathy who had recently been put on warfarin because of a new onset atrial fibrillation. Following his mandatory clotting labs controls, his general practitioner noticed a problem and referred him to the hospital. The patient had a Prothrombin Index of $18 \%$ (normal range $65 \%-120 \%$ ), International Normalized Ratio (I.N.R.) of 4.48 (normal range 2-3), Partial thromboplastin time (PTT) 56.4 seconds (normal range 25 to 35 seconds), fibrinogen $85 \mathrm{mg} / \mathrm{dL}$ (normal range 200-400 mg/dL), D dimer > $20 \mu \mathrm{g} / \mathrm{mL}$ (normal range less than $0.5 \mu \mathrm{g} / \mathrm{mL}$ ), and presented with hematuria and spontaneous ecchymoses throughout the upper limb and trunk. Liver function tests were unremarkable. The patient past medical history showed the diagnosis of a prostate carcinoma (PC) made just by rectal examination and PSA levels measurement two years ago. He was on triptorelin $22.5 \mathrm{mg}$ every six months and denied the performance of a prostate biopsy or an extension study.

Apart from the ecchymoses, physical exam was otherwise normal. In order to rule out internal organ bleeding, Computed Tomography scan was performed and was consistent with a prostatic tumor invading the bladder, the right seminal gland and retroperitoneal pathological lymph nodes (Figure 1). The patient was found to be anemic (hemoglobin $10.8 \mathrm{~g} / \mathrm{dL}$ ) preserving a normal platelet count. As the peripheral-blood smear did not show schistocytes, and antithrombin III serum level was preserved, the diagnosis of a primary hyperfibrinolytic state (PHS), secondary to an advanced and a supposed not-optimized prostate cancer (PC) treatment was suspected. The urologists came along, however, and validated the previously prescribed hormonal 
blockage, that led to the conclusion of a paraneoplastic PHS due to the progression of a solid tumor. An initial therapeutic trial with low dose Low Molecular Weight Heparin (LMWH) was unsuccessful and the patient overall management was supporting-based with fluids, vitamin $\mathrm{K}$ and fibrinogen. He was discharged with neither warfarin nor heparin but on oral tranexamic acid following strict controls on outpatient's clinics. Because he died due to a major bleeding one month afterwards, neither prostate biopsies nor investigations about possible underlying mechanisms were performed.

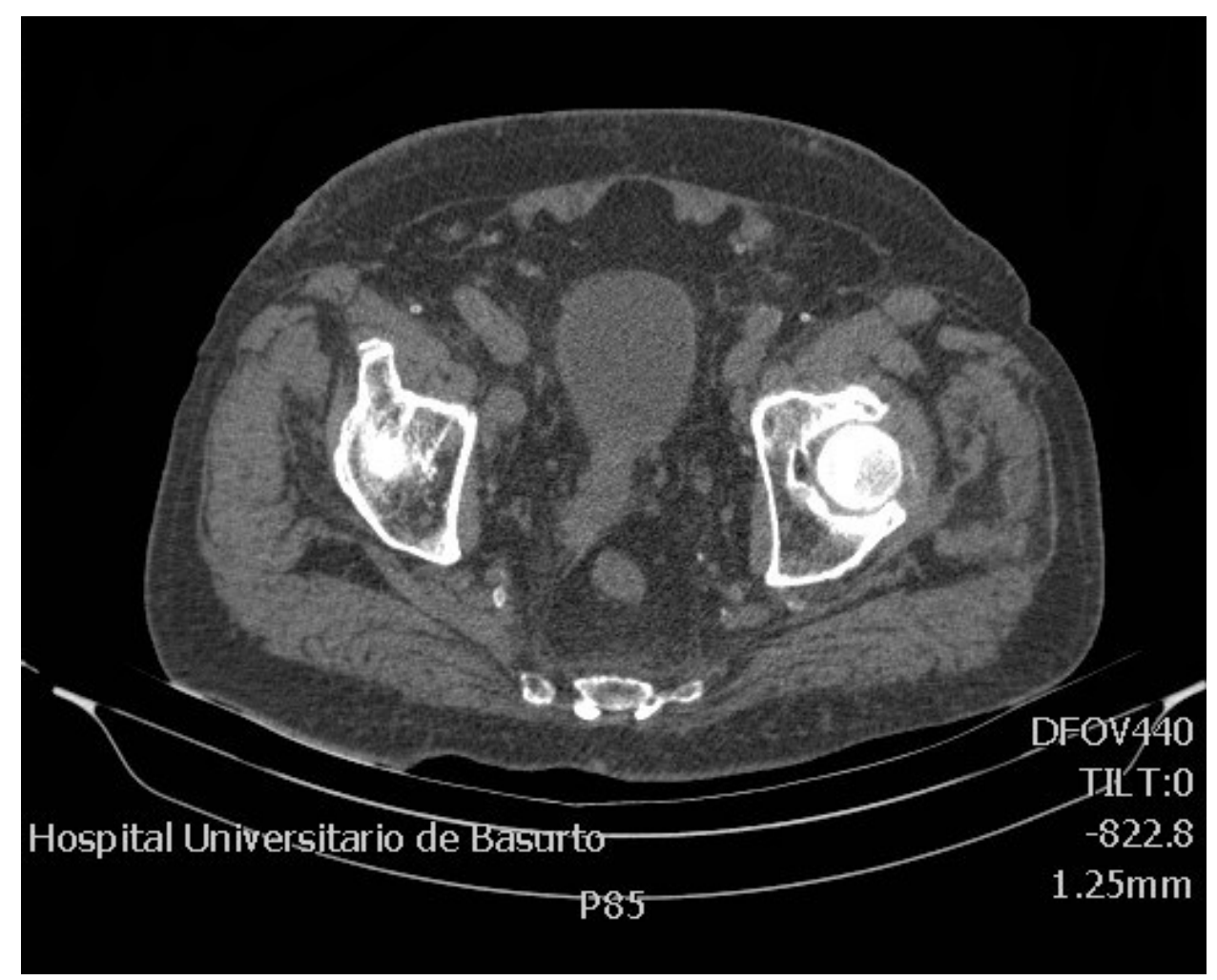

Figure 1. CT scan revealing prostatic tumor invading the bladder, the right seminal gland and retroperitoneal pathological lymphnodes.

As we were not aware of the process extension and the neoplasm baseline-treatment accuracy, we assumed the diagnosis of PHS due to an extended PC.

Our case represents another case of PHS PCrelated $[4,5]$. This infrequent complication, although not exceptional, was a diagnostic challenge for us. In spite of the accomplishment of the laboratory criteria for PHS, we did not take that for granted because of the more common finding of a compensated and platelets-preserved DIC. However, the lack of treatment response to HBPM, the absence of schistocytes and platelet consumption, the high rate of fibrinogen consumption and the evidence of an acute onset led us to the diagnosis of a PHS. As we did not have time to test for plasminogen and clotting factors we are not aware of the underlying mechanisms in our case.

Although prostate blockage is known to maintain under control for a while extended $\mathrm{PC}$ we wonder whether the management would had been different after the performance of a biopsy or an extension study. We want to highlight the rarity of the syndrome, the differential diagnosis, the management issues and the importance of being aware of infrequent presentations of common diseases.

Declaration of interest: There is no conflict of interest and no grant support.

Fibrinoliza primară (FP) este o entitate rară ce se asociază cu mai multe entități clinice şi care poate fi prima formă de prezentare a acestora. Prognosticul FP depinde de patologia cauzatoare. Prezentăm cazul unui pacient cu modificări 
ale coagulării importante ce se asociau malignității. Lipsa diagnosticului corect a impiedicat tratamentul adecvat şi a înrăutățit prognosticul. Diagnosticul greşit al unei entități clinice severe poate duce la pierderea pacientului. Dorim să subliniem raritatea cazului prezentat, diagnosticul diferențial dificil şi importanța de a reține şi diagnosticul de FP. Deoarece pacientul nostru a avut carcinom extins tratamentul curativ nu a putut fi realizat.

Correspondence to: Pablo Ruiz-Sada, MD, Internal Medicine Department, HCU. Basurto (Bilbao), Spain

C/ San Fermín, 38, Ablitas (Navarra), Spain, CP 31523

Telephone: 0034645223946

E-mail: pablitasitas@gmail.com

\section{REFERENCES}

1. RIJKEN D.C., LIJNEN H.R. New insights into the molecular mechanisms of the fibrinolytic system. J ThrombHaemost. 2009;7(1):4-13.

2. TRIPODI A., MANNUCCI P.M. The coagulopathy of chronic liver disease. N Engl J Med. 2011; 365(2):147-56.

3. LEEBEEK F.W., RIJKEN D.C. The fibrinolytic status in liver diseases. Semin Thromb Hemost. 2015 Jul; 41(5):474-80.

4. NAINA H.V.K., PATNAIK M.M., ALI U.A., CHEN D., ASHRANI A.A. Systemic fibrinolysis caused by tissue plasminogen activator-producing metastatic breast cancer. J Clin Oncol. 2010; 28(11):3167-8.

5. OKAJIMA K., KOHNO I., SOE G. Direct evidence for systemic fibrinogenolysis is in patients with acquired alpha 2-plasmin inhibitor deficiency. Am J Hematol 1994; 45:16.

Received November 30, 2015 